\title{
SMES COMPETITIVENESS IN AN INTEGRATED ECONOMY: A PRELIMINARY STUDY FROM INDONESIA
}

\author{
Eko Suseno HR Matrutty ${ }^{1}$, Rosaly Franksisca ${ }^{1}$, Theresia Woro Damayanti ${ }^{2 *}$, \\ Supramono ${ }^{1}$ \\ ${ }^{1}$ Department of Management, Faculty of Economics and Business, Universitas Kristen \\ Satya Wacana, Salatiga, Indonesia \\ ${ }^{2}$ Department of Accounting, Faculty of Economics and Business, Universitas Kristen Satya \\ Wacana, Salatiga, Indonesia \\ dispari.data@gmail.com \\ rosaly.franksiska@staff.uksw.edu \\ woro@staff.uksw.edu \\ supramono@staff.uksw.edu
}

\begin{abstract}
ASEAN Economic Community (AEC) offers both opportunities and challenges to Indonesian Small Medium Enterprises (SMEs). Highly competitive SMEs are likely to exploit opportunities from AEC by expanding their markets and securing raw materials at lower costs. On the contrary, the increasingly intense competition is likely to marginalize less competitive SMEs in their own domestic market. This study aims to analyze the SMEs competitiveness in anticipating AEC. Using 64 SMEs that already export their products or have potentials to export as the sample; this research shows that Indonesian SMEs exhibit a high competitiveness level from the perspective of the production factor, the availability of related and supporting industries factor (especially in relation to the availability of raw and supporting materials), and the demand factor. However, SME owners acknowledge that $A E C$ intensify competition and the government has not provided adequate facilities to improve the SME competitiveness.
\end{abstract}

Keywords: Competitiveness, Diamond Model, SME, AEC.

JEL classification: F02, F15, Z21.

\section{Introduction}

Small and Medium Enterprises (SMEs) play a significant role in supporting ASEAN Economic Community ( $A E C$ ) to integrate the economy of the ASEAN countries as indicated by the fact that SMEs contribute significantly to the ASEAN economy. More specifically, about $96 \%$ of business entities in ASEAN are SMEs. Further, SMEs also contribute to between $30 \%$ and $57 \%$ of gross domestic product and employ about $50 \%$ until $95 \%$ total labor force (Ashariyadi, 2016). Consequently, in AEC 2015 Blueprint, the governments of the ASEAN countries pay greater attention to the development and promotion of SMEs (ASEAN Secretariat, 2015).

SMEs' competitiveness determines their readiness in facing AEC. The ASEAN economy integration offers greater market opportunities that enable competitive SMEs to expand and penetrate to other ASEAN countries' markets. However, competitors from other ASEAN countries are also likely to erode the domestic markets of less competitive SMEs that potentially marginalize these SMEs from their own domestic markets.

The previous discussion about the important role of SMEs in ASEAN economy leads to the issue of the SME competitiveness in Indonesia as the largest ASEAN countries in terms of

* Corresponding Author: Theresia Woro Damayanti 
the number of SMEs. Irjayanti et al. (2016) show that Indonesian SMEs are less ready to anticipate AEC. Similarly, Rifai et al. (2016) also indicate that Indonesian SMEs still need to improve the quality of their products and to optimize the use of technology. Even, a 2014 survey of 310 SME owners in the Central Java Province reveals that $41.6 \%$ of SME owner respondents have no knowledge about AEC (Bank of Indonesia, 2014). This survey indicates that SMEs are less aware of global issues that potentially affect their businesses. In addition, they devote their resources more to internal issues. Overall, this study describes that Indonesian SMEs are much less prepared in anticipating AEC but does not reveal whether this unpreparedness is related to competitiveness. It is therefore interesting to investigate further the competitiveness of Indonesian SMEs in anticipating AEC.

Previous studies on SME competitiveness use different countries as their research context, such as in Hungary (Tantalo, 2012), Ghana (Ocloo et al., 2014), Bulgaria (Ahmedova, 2015), and Thailand (Pongwiritthon \& Awirothananon, 2015). The Indonesian studies mainly focus on specific industries, such as processed food industry (Najib et al., 2015) and furniture industry (Setyawan et al., 2016), or the competitive resources in specific industry cluster (Anton, 2015). These studies are arguably less able to provide a complete description of the competitiveness of Indonesian SMEs especially in relation to the implementation of AEC.

Based on the previous discussion, it is interesting to analyze the competitiveness of Indonesian SMEs that cover various industries, such as wood furniture, TPT, wood processing, food and beverage that have been the Indonesian leading economic sectors. This study uses the "Diamond" Model of Porter (1990) in analyzing the industry competitiveness. This model has been widely used in analyzing the global competitiveness of various industries, such as oil (Galanos \& Masanis, 2010); retail (Pawar Veer, 2013), textile (Mboya and Kazungu, 2015), and sports goods (Jhamb, 2016). As the Diamond Model suggests, we will analyze the competitiveness level based on competitive resources that consist of the condition production factors, demands, support from related industries, and competition.

\section{Literature review}

The Declaration of ASEAN Concord II that will be effective in 2020 stipulates the economic integration of ASEAN that consists of the following countries: Indonesia, Thailand, Malaysia, Singapore, Philippine, Brunei Darussalam, Vietnam, Laos, Myanmar, and Cambodia (ASEAN Secretariat, 2003). However, in the $13^{\text {th }}$ ASEAN Summit Conference in 2007, the ASEAN country leaders agreed to accelerate the implementation of the economic integration or AEC in 2015. It was expected that AEC would create an ASEAN single market and production base that was supported by a free flow of services, investment, capital, and skilled labors. In the AEC 2015 Blueprint, it was mentioned that AEC possess the following four pillars or four key goals: a single market and production base; a highly competitive economic region; a region of equitable economic development; and a region fully integrated into the global economy (ASEAN Secretariat, 2015).

Allen (1963) suggests that the ingredient of an economic integration is eliminating trade barriers between two or more countries. Pangestu and Scollay (2001) also propose that trade; development, politics, and security factors motivate economic integration of developing countries. In a similar vein, Hoekman et al. (2002) emphasize the importance of economic and political factors as the main motives of economic integration. Further, Salvatore (2004) argues that the EU success encourages developing countries to integrate their economy. Meanwhile, enlarging market by expanding the economy of scale and scope, improving resource allocation, and increasing competition to improve economic efficiency and innovation motivate the ASEAN economic integration (Javanoic, 2011).

One can classify the impact of economic integration into two categories (Kosandi, 2012). First, the static effect that refers to the trader and investment effect of economic integration 
on the whole members of the economic integration. Second, the dynamic effect that refers to the impact of economic integration on the regional cohesiveness, convergence, regional peace and stability, diplomatic leverage, and convergence to multilateralism. Previous studies have investigated the static effect of economic integration. For example, Dicaprio et al. (2017) empirically find that members of the economic integration enjoy improved distribution gain from trade activities. However, other studies show different results. For example, Mwasha (2007) shows that the economic integration in Africa through East African Community is ineffective in promoting trade and direct investment because of the low level of resources of the member countries. Further, Paulino (2017) indicates that not all member countries of AAC generate benefits from the economic integration. Less developed country members such as Cambodia, Laos, Myanmar, and Vietnam do not gain benefits from accelerated trade growth due to their deficit trade balance.

What are the effects of AEC implementation on the SMEs as the backbone of the economy of ASEAN countries? SMEs face two challenges: (1) improving competitiveness, and (2) capitalizing opportunities from AEC policy of competitiveness improvement. Competitiveness is the implementation of value-creating strategy by a company and not simultaneously implemented by competitors, and this strategy is not easily duplicated (Porter (1985:102). SMEs in member countries need to improve their competitiveness continuously to gain benefits from the economic integration. If SMEs in certain member countries are complacent with their current competitiveness or having low competitiveness, then it is likely that their business continuity will be under threat. Besides, SMEs should be able to make use opportunities from AEC policies that aim to improve competitiveness. As mentioned in the Blueprint AEC 2015, in order to create a competitive region, ASEAN countries will have business policies of business competition and Intellectual Property Rights protection, jointly build infrastructures, reform tax system, and activate e-commerce. SME competitiveness can be analyzed at the firm, sectoral, and national levels (Petrović el all, 2008). SMEs' individual capabilities to penetrate domestic and international markets that depend on their productivities indicate the firm-level competitiveness. At the sectoral level, Porter (1990) offers the Diamond Model to analyze industry competitiveness based on industries' competitive resources that consist of the condition of production factors, demands, related and supporting industries, and competition. The condition of production factors refers to production inputs such as labor, natural resources, capital, and infrastructures. Demand denotes the ability of domestic markets to function as an important element in enhancing competitiveness. Next, related and supporting industries refers to suppliers and customers. Lastly, firm strategy, structure, and rivalry refer to existing strategy and structure of most firms and competition intensity of certain industries. Porter also adds the role of governments in his analysis, not as an industry player, but as a policy maker through their incentive policy such as subsidy, tax, education, strengthening and empowering production factor condition, and enforcing industry standards. Lastly, the national trade balance identifies the national competitiveness.

\section{Research Method}

This research uses a descriptive analysis method to describe the existing conditions of competitive factors of Indonesian SMEs. The research location is the Central Java Province that contributes a significant number of SMEs in Indonesia and boasts many leading industries.

We select our entrepreneur respondents when they are the owners of SMEs that export their products or have the potentials to export their products so that they have adequate knowledge to assess the impact of the AEC implementation in 2015. This study uses entrepreneurs in various industries to ensure the representativeness of our respondents. We cooperate with the Provincial Office of Industry of the Central Java Province that has 
supervisory authority in various industries. Based on the database of the Provincial Office of Industry of the Central Java Province, the discussion with our informant in the Office, and availability of the potential respondents, we get 64 respondents. Of the 64 respondents, $64 \%$ of them already export their products while the rest (36\%) are still in the category of export potential. Although the respondents involved in this study are relatively small but the respondents are spread across 17 districts / cities and produce various products, ranging from rattan furniture, metal furniture, wooden furniture, cosmetic, plantation products, food and beverage, textile and textile products (TPT), processed woods, to other products.

Table 1: Characteristics of Respondents

\begin{tabular}{|l|c|c|}
\hline Characteristics & Number & Percentage \\
\hline Types of Industries & & \\
\hline Furniture & 18 & $29 \%$ \\
\hline Plantation Products & 5 & $8 \%$ \\
\hline Cosmetics & 2 & $3 \%$ \\
\hline Food and Beverages & 5 & $8 \%$ \\
\hline Processed Woods & 11 & $17 \%$ \\
\hline Textile and Textile Products (TPT) & 16 & $25 \%$ \\
\hline Others & 7 & $11 \%$ \\
\hline Labor Education & & \\
\hline Primary School & 2 & $3 \%$ \\
\hline Junior High School & 13 & $20 \%$ \\
\hline Senior High School & 38 & $59 \%$ \\
\hline Diploma & 3 & $5 \%$ \\
\hline Bachelor & 8 & $13 \%$ \\
\hline Export Activity & & \\
\hline Export Potential & 23 & $36 \%$ \\
\hline Already Export & 41 & $64 \%$ \\
\hline
\end{tabular}

Source: Field Survey, 2016

Our questionnaire combines open-ended questions with the close-ended ones to enable the interviewers to generate information about SMEs' competitiveness as suggested by the Porter's Diamond Model. The Porter's Diamond Model consists of the condition of production factors, demand condition, competition, related and supporting industries, and government. We operationalize each factor into 4 to 5 question items. We measure each item based on the 5-point ratings of agreement ( $1=$ Strongly disagree, $5=$ Strongly agree).

\section{Results and Discussion}

\subsection{SMEs Market}

Our SME owner respondents have extensive export markets, in not only ASEAN countries but also other countries such as Germany, Poland, USA, Saudi Arabia, China, Japan, India, Pakistan, Hong Kong, Australia, Canada, Italy, Mexico, and Dubai. The number of SMEs that export their products to other ASEAN countries increases from 29 in 2014 to 34 in 2015. Similarly, those who export to non-ASEAN countries increase from 27 SMEs to 30.

AEC began to be implemented at the end of 2015, or more precisely, on December 31 , 2015. It is expected that AEC increases the inter-country flow of goods within ASEAN region. On average, the export value before AEC is Rp $179,512,227,763.00$ and increases to $R p$ $182,737,793,517.00$ after the implementation of AEC. This increase is not significant. Only the processed wood and plantation product exhibits an export decrease while wooden furniture, food and beverage, textile and textile products, cosmetics and other products 
exhibit export increases after the implementation of AEC. Import activity is only done by wooden furniture, food and beverage, processed wood, textile and textile products. The average import value before AEC is Rp 113,425,386,819.00 and Rp 111,835,377,057.00 after the implementation of AEC, indicating an insignificant decline. However, the processed woods and TPT exhibit significant import decline.

Table 2: Import Export Activities Before and After AEC

\begin{tabular}{|l|r|r|c|}
\hline Panel A. Export of SMEs to ASEAN Countries \\
\hline & \multicolumn{1}{|c|}{ Before AEC } & \multicolumn{1}{c|}{ After AEC } & $\boldsymbol{p}$-value \\
\hline Total Industry & $179,512,227,763.44$ & $182,737,793,517.51$ & 0.632 \\
\hline Wooden Furniture & $3,676,262,015.06$ & $5,109,271,954.89$ & 0.468 \\
\hline Food and Beverage & $23,557,033,748.89$ & $30,776,785,266.67$ & 0.330 \\
\hline Processed Wood & $73,406,592,050.92$ & $61,119,749,191.00$ & 0.580 \\
\hline Textile and Textile Products & $14,104,188,372.64$ & $18,800,868,650.55$ & 0.178 \\
\hline Plantation Products & $3,075,000,000.00$ & $4,000,000,000.00$ & 0.249 \\
\hline Cosmetics & $13,987,952,785.63$ & $13,368,158,830.00$ & 0.771 \\
\hline Others & $47,705,198,790.31$ & $49,562,959,624.40$ & 0.681 \\
\hline Panel B. Import of SMEs to ASEAN Countries \\
\hline \multicolumn{4}{|c|}{} \\
\hline Total Industry & Before AEC & After AEC & $\boldsymbol{p}$-value \\
\hline Wooden Furniture & $113,425,386,819.69$ & $111,835,377,057.66$ & 0.133 \\
\hline Food and Beverage & $82,741,304,674.89$ & $91,805,731,554.33$ & 0.211 \\
\hline Processed Wood & $2,278,660,034.80$ & $1,811,112,400.00$ & 0.324 \\
\hline Textile and Textile Products & $23,604,526,703.33$ & $14,867,453,770.00$ & $0.033^{\star *}$ \\
\hline
\end{tabular}

Source: Field Survey, 2016

Note: ${ }^{* *},{ }^{*}=$ significant at $5 \%, 10 \%$, respectively

\subsection{SMEs Competitiveness}

Competitiveness is business entities' capability to survive in the competition against their competitors. In this research context, competitors are those from other ASEAN countries. There are four factors that determine competitiveness, namely production factor condition, demand, competition, related and supporting industries, and government as an external factor.

Our data indicate that SMEs exhibit a high level of competitiveness in anticipating AEC because of two main factors, i.e., low labor costs and easy access to capital. The demand factor, that represents the capability to produce high-quality products and to meet market demands, also exhibits high scores. A high level of international demand, SMEs' capabilities to produce high-quality products, and innovative capabilities of SMEs to meet market demands also facilitate a high competitiveness level from the demand factor.

From the competition factor, SME owners exhibit a low competitiveness score. High competition levels in the export and import markets erode SMEs' competitiveness in the competition factor. However, our respondents mention that they already have certain competitive strategies to compete. 
Table 3: Competitive Condition of SMEs - Related Samples Wilcoxon Signed Rank Test

\begin{tabular}{|c|c|c|c|}
\hline & $\begin{array}{c}\text { Competitiveness } \\
\text { Score }\end{array}$ & Sign & Significance \\
\hline Production Factor Condition & 3.33 & + & $0.000^{\star \star \star}$ \\
\hline Availability of Skilled Labor & 3.20 & + & 0.157 \\
\hline Cheap Labor Cost & 3.32 & + & $0.000^{* * *}$ \\
\hline $\begin{array}{l}\text { Support of Production Facilities } \\
\text { and Infrastructure }\end{array}$ & 3.59 & + & 0.243 \\
\hline Access to Capital & 3.46 & + & $0.001^{* * *}$ \\
\hline Demand Factor & 3.67 & + & $0.000^{\star \star \star}$ \\
\hline A High Level of Domestic Demand & 3.26 & + & 0.243 \\
\hline $\begin{array}{l}\text { A High Level of International } \\
\text { Demand }\end{array}$ & 3.70 & + & $0.000^{\star \star *}$ \\
\hline $\begin{array}{l}\text { Capability to Produce High-Quality } \\
\text { Products }\end{array}$ & 4.07 & + & $0.000^{* * *}$ \\
\hline $\begin{array}{l}\text { Innovative Capability to Meet } \\
\text { Market Demands }\end{array}$ & 3.86 & + & $0.000^{* * *}$ \\
\hline Competition Factor & 2.08 & - & $0.000^{\star \star \star}$ \\
\hline $\begin{array}{l}\text { A High Level of Competition in the } \\
\text { Domestic Market }\end{array}$ & 1.31 & - & $0.000^{* * *}$ \\
\hline $\begin{array}{l}\text { A High Level of Competition in the } \\
\text { Export Market }\end{array}$ & 1.05 & - & $0.000^{\star \star *}$ \\
\hline $\begin{array}{l}\text { Possession of Competitive } \\
\text { Strategy }\end{array}$ & 3.63 & + & $0.000^{* * *}$ \\
\hline $\begin{array}{l}\text { Related and Supporting Industries } \\
\text { Factor }\end{array}$ & 3.53 & + & $0.000^{\star \star \star}$ \\
\hline Availability of Raw Materials & 3.53 & + & $0.001^{\star * *}$ \\
\hline Ease of Raw Materials Acquisition & 3.47 & + & $0.003^{* * *}$ \\
\hline Proportion of Local Raw Materials & 3.70 & + & $0.000^{* \star *}$ \\
\hline Availability of Supporting Materials & 3.61 & + & $0.000^{* * *}$ \\
\hline $\begin{array}{l}\text { Ease of Supporting Material } \\
\text { Acquisition }\end{array}$ & 3.63 & + & $0.000^{* * *}$ \\
\hline Government & 2.40 & - & $0.000^{\star \star \star}$ \\
\hline $\begin{array}{l}\text { Development of human resource } \\
\text { competence }\end{array}$ & 2.88 & - & $0.041^{* *}$ \\
\hline $\begin{array}{l}\text { Advocacy in production } \\
\text { technology and design }\end{array}$ & 2.49 & - & $0.067^{*}$ \\
\hline Advocacy in Access to Capital & 2.51 & - & $0.059^{*}$ \\
\hline $\begin{array}{l}\text { Support in Production Equipment } \\
\text { Acquisition }\end{array}$ & 2.09 & - & $0.000^{* * *}$ \\
\hline Support in Marketing Activities & 2.46 & - & $0.000^{* * *}$ \\
\hline
\end{tabular}

Source: Field Survey, 2016

Notes: ${ }^{* * *},{ }^{* *},{ }^{*}=$ significant at $1 \%, 5 \%$, and $10 \%$ levels, respectively

From the supporting and related industries, SMEs exhibit high competitiveness levels for all items (availability of raw materials, ease of raw material acquisition, the proportion of local raw materials, availability of supporting materials, ease of supporting materials acquisition, and proportion of local supporting materials). However, our respondents perceive the government factor to contribute less to increase their competitiveness. Relatively low scores of development of human resource competence, advocacy in the production technology and design, advocacy in access to capital, support in the acquisition of production equipment, 
support in marketing activities, and provision of certain incentives / subsidies indicate the perception.

From Porter's perspective, the interaction of the five factors determines the international competitiveness.

Tabel 4: The Relation Between Competitiveness Factors-Correlation Analysis

\begin{tabular}{|c|c|c|c|c|c|}
\hline & $\begin{array}{c}\text { Production } \\
\text { Factor } \\
\text { Condition }\end{array}$ & $\begin{array}{l}\text { Demand } \\
\text { Factor }\end{array}$ & $\begin{array}{c}\text { Competition } \\
\text { Factors }\end{array}$ & $\begin{array}{c}\text { Related and } \\
\text { Supporting } \\
\text { Industries } \\
\text { Factor }\end{array}$ & Government \\
\hline $\begin{array}{l}\text { Production } \\
\text { Factor } \\
\text { Condition }\end{array}$ & 1 & $\begin{array}{c}0.648 \\
(0.000)^{\star * *}\end{array}$ & $\begin{array}{c}-0.336 \\
(0.011)^{\star *}\end{array}$ & $\begin{array}{c}0.390 \\
(0.003)^{\star * *}\end{array}$ & $\begin{array}{c}0.235 \\
(0.079)^{*}\end{array}$ \\
\hline $\begin{array}{l}\text { Demand } \\
\text { Factor }\end{array}$ & $\begin{array}{c}0.648 \\
(0.000)^{\star * *}\end{array}$ & 1 & $\begin{array}{c}-0.381 \\
(0.003)^{* * *}\end{array}$ & $\begin{array}{c}0.292 \\
(0.028)^{\star *}\end{array}$ & $\begin{array}{c}0.256 \\
(0.055)^{\star}\end{array}$ \\
\hline $\begin{array}{l}\text { Competition } \\
\text { Factor }\end{array}$ & $\begin{array}{c}-0.336 \\
(0.011)^{\star *}\end{array}$ & $\begin{array}{c}-0.381 \\
(0.003)^{\star * *}\end{array}$ & 1 & $\begin{array}{c}0.376 \\
(0.004)^{\star \star \star}\end{array}$ & $\begin{array}{c}0.342 \\
(0.009)^{\star \star \star}\end{array}$ \\
\hline $\begin{array}{l}\text { Related and } \\
\text { Supporting } \\
\text { Industries } \\
\text { Factor }\end{array}$ & $\begin{array}{c}0.390 \\
(0.003)^{\star \star \star}\end{array}$ & $\begin{array}{c}0.292 \\
(0.028)^{\star *}\end{array}$ & $\begin{array}{c}0.376 \\
(0.004)^{\star \star \star}\end{array}$ & 1 & $\begin{array}{c}0.044 \\
(0.748)\end{array}$ \\
\hline Government & $\begin{array}{c}0.235 \\
(0.079)^{*}\end{array}$ & $\begin{array}{c}0.256 \\
(0.055)^{\star}\end{array}$ & $\begin{array}{c}0.342 \\
(0.009)^{\star * *}\end{array}$ & $\begin{array}{c}0.044 \\
(0.748) \\
\end{array}$ & 1 \\
\hline
\end{tabular}

Source: Field Survey, 2016

Notes: ( ) shows the value of significance

${ }^{* \star *},{ }^{* *},{ }^{*}=$ significant at $1 \%, 5 \%$, and $10 \%$ levels, respectively

Table 4 shows that SMEs' production factor condition is associated with the demand factor, competition factor, related and supporting industries factor, and government factor. The demand factor is also closely related to the competition factor, related and supporting industries factor, and government factor. Further, the competition factor is also associated with the supporting industries factor and government factor. However, the supporting industries factor exhibits no significant association with the government factor. Mostly, all factors of SME competitiveness interact each other, except for the supporting industries factor and the government factor. These interactions significantly facilitate SMEs in positioning towards AEC. Therefore, we can construct the following map of SME competitiveness: 


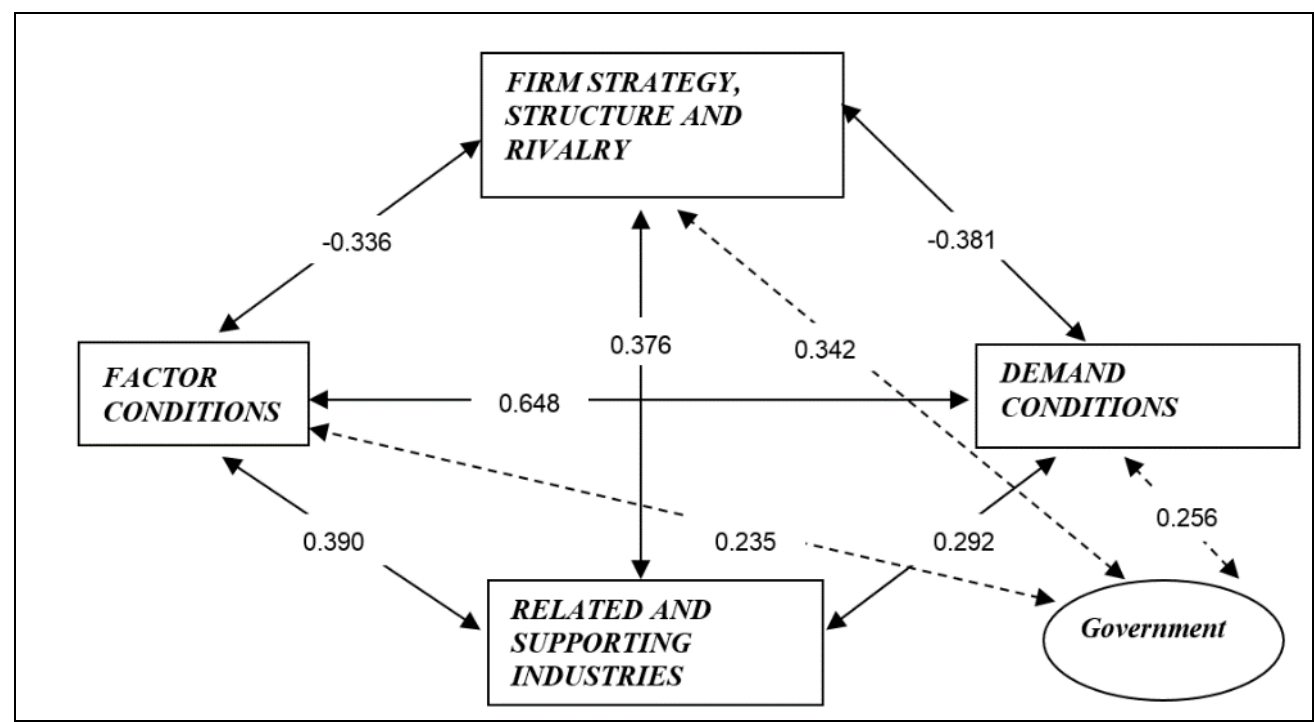

Figure 1: SMEs Competitiveness in AECSource: Field Survey, 2016

\section{Conclusions}

After the implementation of AEC, the export-import activities do not exhibit a significant increase relative to the pre-AEC period. These indicate that (1) SMEs survive the ASEAN market after the implementation of AEC, and (2) SMEs cannot significantly improve their competitiveness in the ASEAN market after the implementation of AEC.

Our preliminary study shows that Indonesian SMEs can improve their competitiveness significantly if there are sufficient supports of (a) production factor, in the form of skilled labor, low labor cost, production facilities and infrastructure, and access to capital; b) related and supporting industries to ensure the availability of raw and supporting materials; c) demand factor, related to a high level of the domestic and international market, the capability to produce high-quality products and innovative capabilities to meet market demands. However, SME owners acknowledge that the implementation of AEC increases competition intensity, while the government has not provided adequate support to improve the competitiveness of SMEs.

\section{Suggestions}

Our observation period is relatively very short and also the sample size is small. Therefore, our findings are subject to some caveats, especially in interpreting the post-AEC export-import performance of SMEs that continuously increase. However, based on the findings, we propose the following policy recommendations to improve the competitiveness of Indonesian SMEs. First, it is necessary for the government to intensify the socialization of AEC implementation and its impact on SMEs because many SMEs are not aware of AEC, let alone the impact of the implementation of AEC. Second, the government should continuously increase the competitiveness of SMEs in anticipating AEC because SMEs consider the role of the government is still limited. The government can support SMEs by improving human resource competence and production technology and design, supporting the acquisition of production equipment, promoting access to capital, facilitating marketing activities, and provision of certain incentives/ subsidies. 


\section{References}

Ahmedova, S., 2015. Factors for Increasing the Competitiveness of Small and Medium-Sized Enterprises (SMEs) In Bulgaria. Procedia - Social and Behavioral Sciences, 195, pp.1104-1112.

Allen, R., L., 1963. Review of The Theory of Economic Integration. Economic Development and Cultural Change, 11(4), pp. 449-454.

Anton, S.,A., Muzakan, A., and Muhammad, W.,F., 2015. An Assessment of SME Competitiveness in Indonesia. Journal of Competitiveness, 7 (2), pp. 60 - 74.

ASEAN Secretariat, 2003. Declaration of ASEAN Concord II (Bali Concord II), Jakarta: ASEAN Secretariat, Oktober.

ASEAN Secretariat, 2015. ASEAN Economic Community Blueprint 2025, Jakarta: ASEAN Secretariat, November.

Bank Indonesia, 2014. Kesiapan UKM Menghadapi MEA, Semarang: Kantor Bank Indonesia.

DiCaprio, A., Santos-Paulino A.U. and Andokolova, 2017. Regional Integration, Trade Agreements and Development. UNCTAD Research Paper no.1.

Hoekman, B., Matoo, A. and English, P., 2002. Development, Trade and the WTO, The World Bank.

Galanos, G. and Manasis, G., 2010. Analysis of Competitiveness of Greek's Olive Oil Sector using Porter's Diamond Model. Research Journal of International Studies, 16, pp. 33-46.

Irjayanti, M., Azis, A.,M., and Sari, P., A., 2016. Indonesia SMES Readines For Asean Economic Community. Actual Problems of Economic, 3(177), pp. 31-38.

Jovanovic, M., 2011. International Handbook on the Economics of Integration. Volume II. UK: Edward Elgar.

Jhamb, P., 2016. An Application of Porter's Diamond Framework: A Case of Sports Goods Cluster at Jalandhar. Pacific Business Review International, 8 (8), pp.141-146.

Kosandi, M., 2012. Parallel Evolution of Practice and Research on ASEAN Economic Integration: From Paradigm Contestation to Eclectic Theorization. The International Studies Association of Ritsumeikan University, 11, pp. 101-133.

Mboya, J. and Kazungu, K., 2015. Determinants of Competitive Advantage in the Textile and Apparel Industry in Tanzania: The Application of Porter's Diamond Model. British Journal of Economics, Management \& Trade, 7(2), pp. 128-147.

Mwasha, O.,N., 2007. The Benefits of Regional Economic Integration for Developing Countries in Africa: A Case of East African Community (EAC). Korea Review of International Studies, pp. 69-92.

Najib, M., Kiminanmi, A. and Yagi, H., 2011. Competitiveness of Indonesian Small and Medium Food Processing Industry: Does the Location Matter? International Journal of Business and Management, 6 (9), pp. 57-67.

Ocloo, C.,E., Akaba,S. and Worwui-Brown,D.K., 2014. Globalization and Competitiveness: Challenges of Small and Medium Enterprises (SMEs) in Accra, Ghana. International Journal of Business and Social Science, 5 (4), pp. 287-296.

Pangestu, M. and Scollay, R., 2001. Regional Trading Arrangements: Stocktake and Next Steps. Trade Policy Forum, Bangkok, Thailand.

Pawar, P.,A. and Veer, N.,B., 2013. Competitive Advantage of India for FDI in Retail: A Porter's Diamond Approach. Annual Research Journal, 1, pp.69-83.

Paulino, A.,U.,A., 2017. The Asian Economic Integration Cooperation Agreement: Lessons for Economic and Social Development. UNCTAD Research Paper No. 3.

Petrović, P., Antevski, M. and Vesić, D., 2008. The International Competitiveness and Economic Integration. ACTA UNIVERSITATIS Series: Economics and Organization, 5 (1), pp. 1-8. 
Pongwiritthon, R. and Awirothananon, T., 2015. Competitive Advantages of Small and Medium Enterprises in Northern Thailand, Journal of US-China Public Administration, 12 (1), pp. 42-50.

Porter, M. E., 1985. Competitive Advantage: Creating and Sustaining Superior Performance. New York.

Porter, M.E., 1990. The Competitive Advantage of Nations. New York: Free Press.

Rifai, M., Indrihastuti, P., Sayekti, N.,C. and Gunawan, C.,I., 2016. Competitive Readiness from Indonesia's Small and Medium Industry (SME) in Dealing with ASEAN Economic Community. International Journal of Advance Research, 4 (4), pp.52-59.

Salvatore, D. , 2006. International Economics. 8Ed, Willey International Edition, USA.

Setyawan, R., E., Daryanto, H.,K. and Oktaviani,R., 2016. Strategi Peningkatan Daya Saing Industri Furniture Rotan. Jurnal Manajemen \& Agribisnis, 13 (3), pp.169-182.

Tantalo, C., Caroli, M.G. and Vanevenhoven, J., 2012. Corporate Social Responsibility and SME's competitiveness. Int. J. Technology Management, 58 (1/2), pp.129-151.

\section{Bio-note}

Eko Suseno HR Matrutty, MM, is a lecturer in Department of Management, Faculty of Economics and Business, Universitas Kristen Satya Wacana. His areas of interest are strategic marketing and Small Medium Enterprises.

Rosaly Franksisca, MBA, is a lecturer in Department of Management, Faculty of Economics and Business, Universitas Kristen Satya Wacana. Her areas of interest is human resource management.

Theresia Woro Damayanti, Dr, is a associate professor in Department of Accounting, Faculty of Economics and Business, Universitas Kristen Satya Wacana. Her areas of interest are accounting and taxation.

Supramono, $D B A$, is a professor in Department of Management, Faculty of Economics and Business, Universitas Kristen Satya Wacana. His areas of interest are strategic management and behavioral finance. 